Thorax, 1980, 35, 241-245

\title{
Editorial
}

\section{Occupational asthma}

Occupational asthma is variable airways narrowing causally related to exposure in the working environment to airborne dusts, gases, vapours, or fumes. It affects only a proportion (usually a minority) of those exposed to the agents which cause the disease, and develops only after an initial symptom-free period of exposure, which may vary between individuals from weeks to years. Asthmatic reactions tend to recur on reexposure to the causal agent at atmospheric concentrations not affecting others similarly exposed. Such findings fulfil the classical clinical criteria of hypersensitivity, and it is not surprising that much of the investigation of occupational asthma has been directed towards indentification of underlying immunological mechanisms. Its importance, however, is much wider than its interest to immunologists. Avoidance of exposure to the causal agent can be followed by complete remission of symptoms and restoration of normal lung function. Knowledge of the characteristic features of the disease is important for those to whom such patients may present. Occupational asthma is also a potentially preventable disease. Identification of a particular agent as a cause of occupational asthma should represent the first step towards prevention of the disease.

The number of agents to which exposure occurs at work which have been reported as causing asthma now exceeds 200. Those best recognised in the United Kingdom are listed in the table with some of the more common circumstances in which they may be encountered. It can be expected, with the increasing recognition of occupational asthma and the continuous introduction of new materials into industrial processes, that this list will grow.

The relative importance of occupational exposures as causes of asthma is unknown. In Finland where occupational asthma is a prescribed disease, 80 new cases were reported to the Finland Occupational Diseases Register in 1976. ${ }^{1}$ No such register exists as yet in the United Kingdom. Prevalence studies of working

Address for reprint requests: Dr AJ Newman Taylor. Brompton Hospital, Fulham Road, London SW3 6HP. populations exposed to particular causes of occupational asthma have frequently shown a relatively high proportion of those at risk to be affected. Twenty-two per cent of 446 shop floor employees of an electronics factory where colophony was used as a soft solder flux had work-related respiratory symptoms, compared with a prevalence of similar symptoms in only $6 \%$ in those working in other parts of the factory. ${ }^{2}$ A significantly greater proportion of employees leaving during the three and a half years before the survey had worked on the shop floor than in other parts of the factory; this difference could largely be accounted for by the departure of those with work-related respiratory symptoms. ${ }^{3}$ Of the 21 patients originally studied by Burge and colleagues, ${ }^{4}$ five had pre-existing asthma and 14 had never smoked. Nevertheless, 19 were initially diagnosed as having "bronchitis". In a prevalence survey of 146 current employees in an animal laboratory, allergic reactions to one or more of the animals with which they worked were found in $30 \%$, of whom one-third had asthmatic symptoms provoked by animal exposure. ${ }^{5}$ In a study of employees in an Australian factory manufacturing enzyme detergents, 49 of the 98 workers interviewed had work-related asthmatic symptoms. ${ }^{6}$

The most characteristic symptom of occupational asthma is episodic breathlessness temporally related to occupational exposures. Those affected may themselves appreciate that their symptoms develop during the working week, often increasing in severity as the week progresses, and improve at times of absence from work such as at weekends or on holidays, only to recur on return to work. Symptoms may develop within minutes of exposure (immediate) or only several hours after the onset of exposure (late), either during that latter part of the working day or in the evening after returning home. Of 49 enzyme detergent industry workers with asthma. ${ }^{\circ}$ symptoms were immediate in 13 and late in 36 . A similar bimodal pattern of symptoms was reported in study of electronics industry employees. $^{7}$ On occasions the relationship 
Table Summary of main agents causing occupational asthma

\begin{tabular}{|c|c|}
\hline Causal agents & Circumstances of exposure \\
\hline $\begin{array}{l}\text { Biological causes } \\
\text { B subtilis enzymes (Alcalase etc) } \\
\text { Small mammal urine proteins (rats, mice etc) } \\
\text { Grain and flour } \\
\text { Wood dusts (Western red cedar/Iroko etc) } \\
\text { Colophony (as soft solder flux) } \\
\text { Antibiotics (penicillins etc) } \\
\text { Chemical causes }\end{array}$ & $\begin{array}{l}\text { Enzyme detergent industry } \\
\text { Animal laboratory workers } \\
\text { Food industry (millers, bakers etc), farmers } \\
\text { Wood mills, carpenters } \\
\text { Electronics industry } \\
\text { Pharmaceutical industry }\end{array}$ \\
\hline $\begin{array}{l}\text { Di-isocyanates (toluene (TDI), diphenylmethane (MDI), hexamethylene } \\
\text { (HDI), and naphthalene (NDI)) }\end{array}$ & $\begin{array}{l}\text { Polyurethane foam manufacture } \\
\text { Printing industry } \\
\text { Synthetic paints and rubber adhesives }\end{array}$ \\
\hline $\begin{array}{l}\text { Epoxy resin curing agents (phthalic anhydride, trimellitic anhydride, } \\
\text { triethylene tetramine etc) } \\
\text { Complex salts of platinum (particularly ammonium hexachlorplatinate) } \\
\text { Formaldehyde }\end{array}$ & $\begin{array}{l}\text { Surface coatings } \\
\text { Adhesives } \\
\text { Platinum refining } \\
\text { Laboratory workers }\end{array}$ \\
\hline
\end{tabular}

between symptoms and exposure may be unclear, symptoms persisting for several days or even weeks after exposure has ceased. Symptoms which fail to improve over a weekend by no means exclude the diagnosis of occupational asthma; failure to notice either improvement during a two-week holiday, or subsequent deterioration on returning to work would, however, be unusual. Patients with occupational asthma may also find that in addition to occupational exposures, other stimuli such as exercise, upper respiratory tract infections, and emotional upset also provoke asthmatic reactions.

Ideally any patient diagnosed as having occupational asthma should avoid further exposure to the causal agent. This may involve relocation within an organisation or loss of current employment. Such recommendations can only be made where the physician is confident that the patient's symptoms are related to an occupational exposure, which generally requires some objective evidence of the relationship. Inhalation testing with the suspected agent for short periods under controlled conditions was developed for this purpose. Such tests are potentially hazardous and should only be conducted by those experienced in their techniques. They are also very demanding on resources; individuals on whom such tests are conducted must be admitted to hospital for observation by medical staff for at least 24 hours after testing. Alternative methods for diagnosing occupational asthma have therefore been introduced, and are being increasingly used.

Skin prick test reactions are elicited in sensitised individuals by a number of agents causing occupational asthma, including the $B$ subtilis enzyme, Alcalase, the complex platinum salt, ammonium hexachlorplatinate, wheat and rye flour, and rat and mouse urine. Mitchell and Gandevia $^{B}$ found that an immediate skin test reaction to Alcalase lacked both sensitivity and specificity as an index of work-related asthmatic symptoms. A positive immediate skin test reaction to the appropriate allergen has, however, bee found to be both a sensitive and specific test f\& disease caused by allergy to rat urine protein $\$$ and the complex salts of platinum. ${ }^{9}$ Furthes evaluation of skin test reactions to these and other occupational allergens in exposed populations required.

When seen outside their place of work man patients with occupational asthma have either normal lung function or airway narrowing wit out improvement after bronchodilator inhalation. More than $50 \%$ of a group of solderers seen the Brompton Hospital in whom the diagnosis occupational asthma was later confirmed oy inhalation testing failed in routine lung function tests to improve their forced expiratory volunge in one second $\left(F E V_{1}\right)$ by $15 \%$ after inhalation of a standard dose of bronchodilator. ${ }^{10}$ Measur8. ments of lung function (usually PEF recorded the subject) during periods at work compared wigh similar measurements during absences from work have been used to validate the relationship between asthma and occupational exposure. The analysis and interpretation of the differences observed here have been made difficult several factors. Great intersubject variation found in the interval between the onset of occ 5 pational exposure and the development of changes in lung function, as well as in the tinfe taken for lung function abnormalities to recover after exposure has ceased. Often a marked diurnal variation in airway calibre develops, with maximal narrowing when away from work during the night or on waking in the morning. Sing pre- and post-shift measurements of lung function are always inadequate and often misleading. The difference in mean daily PEF measurements 
a number of workers reacting to colophony:" and to di-isocyanates ${ }^{11}$ made at one to two hourly intervals from waking to sleeping between periods at work and absences from work (provided these were of sufficient duration) was found to be both a sensitive and specific index of work-related asthma.

The development of serological tests in the diagnosis of occupational asthma is still in its infancy, but in the past two years different groups have reported methods for demonstrating specific IgE or IgG antibodies for both TDI, ${ }^{12}$ MDI, ${ }^{13}$ trimellitic acid, ${ }^{14}$ phthalic acid, ${ }^{15}$ and ammonium hexachlorplatinate. ${ }^{16}$ If these findings are validated and the methods can be introduced into general clinical practice, the diagnosis of occupational asthma will be greatly simplified.

What then is the present place of inhalation testing? Four important indications remain: where an individual is suspected of reacting to an agent as yet unrecognised as causing occupational asthma; where, as may occur, an individual with work-related asthma is exposed to several recognised causes of occupational asthma; where genuine doubt about the diagnosis of occupational asthma remains after all other appropriate investigations (including work records of PEF measurements) have been completed; and where the symptoms experienced at work are of such severity that it is thought to be unjustifiable for the patient to be further exposed to the working environment. Inhalation testing whose sole purpose is in support of a legal claim is, I believe, unjustified.

The long-term effect on respiratory function of those with occupational asthma who have ceased exposure to the causal agent has been little studied. Clinical studies suggest that asthma persists in a proportion of those with occupational asthma, who previously were without respiratory symptoms. Chan Yeung ${ }^{17}$ found that eight of 38 patients with inhalation test proven Western red cedar asthma had persistent asthma, not attributable to other causes, six months or more after their last exposure. In a case control analysis of 46 TDI sensitive men who had ceased exposure for between two and 11 years, Adams ${ }^{18}$ found a significant excess of respiratory symptoms in the TDI sensitive group.

Management of the established case is based wherever possible on the necessity of avoiding further exposure to the causal agent. The most satisfactory solution, if practicable, is alternative employment within the same organisation. Relocation, however, may not be possible in small firms, particularly if a relatively large number of employees have been affected, or for those whose work is very specialised, such as a chemist working with di-isocyanates, or a pharmacologist conducting experiments on small mammals. In such situations avoidance of further exposure can only be achieved by leaving current employment. For social and financial reasons the affected individual, fully aware of the potential risks to his health, may choose to continue in his present employment, and other less medically satisfactory measures have to be adopted. At present these rely primarily on the use of personal protection with or without the administration of prophylactic drugs. Where such measures are adopted their effectiveness should be monitored. For this purpose regular measurements of PEF during periods of protected exposure compared with similar measurements made during absences from exposure have proved valuable.

The recognition and management of occupational asthma are important clinical problems, but occupational asthma is also a problem of prevention. "Find a safe substitute" is a wellrecognised maxim of occupational health practice and is the ideal method of prevention. Occupational asthma in printers caused by gum acacia used as an anti set-off spray ${ }^{19}$ has been eliminated since its substitution by dextrose. Alternatives to colophony for use as a soft solder flux are currently being investigated, as are methods for platinum refining not involving the production of ammonium hexachlorplatinate as an intermediate. In the absence of a safe substitute the concentration of the con aminant in the environment must be controlled to levels within which the great majority of those exposed can work without risk of adverse effect. Those who can be identified as particularly susceptible to the effects of a specific agent should also be excluded from exposure.

Exposure to airborne contaminants can be controlled by well-tried methods of industrial hygiene such as enclosing the process, removing contaminants at source by local exhaust ventilation, limiting the numbers exposed to a hazard by segregation of the process, and least satisfactorily, personal protection. Design and construction of a safe working environment is the business of the engineer. Assessment of the degree of control necessary to provide a safe working environment, however, can only sensibly be based on a knowledge of the relationship between exposure to the particular hazard and disease frequencythat is, the dose-response relationship. The current threshold limit value for cotton dust of $1 \mathrm{mg} / \mathrm{m}^{3}$ is based on a study of the prevalence of 
byssinosis in five cotton mills with very different dust exposures. ${ }^{20}$ The prevalence of byssinosis was related linearly to total dust exposure, with a threshold concentration of $1 \mathrm{mg} / \mathrm{m}^{3}$. No workers exposed to $1 \mathrm{mg} / \mathrm{m}^{3}$ had grade 1 or grade 2 byssinosis. An important problem requiring particular attention in the investigation of dose-response relationships for occupational asthma is the relationship between intensity and duration of exposure. In most studies of occupational lung disease (such as asbestosis and coalworkers' pneumoconiosis) the estimate of total dust exposure is based upon the assumption that intensity and duration of exposure are equivalent. Such an assumption cannot be made reliably for the majority of causes of occupational asthma. Exposure to high concentrations of TDI for a short period may well be more hazardous than exposure to a lower concentration for a longer period which is equivalent as a time weighted average. To date no studies of such dose-response relationships of agents causing occupational asthma have been published. The analysis of such relationships, including the relationship between intensity and duration of exposure as a scientific basis for hygiene standards is the most urgent task facing those interested in the prevention of occupational asthma.

Atopics (defined as individuals in whom one or more positive skin prick test reactions can be elicited by common inhalant allergens), to date the only group identified as being particularly at risk of developing occupational asthma, should be excluded from working with the two agents to which they have been shown to be susceptible-$B$ subtilis enzymes ${ }^{21}$ and the complex salts of platinum. ${ }^{9}$ There is at present no evidence of particular susceptibility to any other agents causing occupational asthma, and it is therefore inappropriate to exclude atopics (who may constitute more than $40 \%$ of the general population during the thind decade) in other circumstances.

Occupational asthma is an important diagnostic challenge for physicians working in and outside industry. It is also an unusual chance for physicians to collaborate with epidemiologists, industrial hygienists, chemists, and engineers in a genuine opportunity for prevention.

A J NEWMAN TAYLOR

Brompton Hospital

London

\section{References}

1 Keskinen H, Alanko K, Saarinen L. Occupational asthma in Finland. Clin Allergy 1978; 8:569-80.

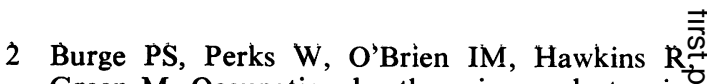
Green M. Occupational asthma in an electronics factory. Thorax 1979; 34:13-8.

3 Perks WH, Burge PS, Rehahn M, Green $M_{\bar{C}}^{\frac{\bar{\omega}}{\sigma}}$ Work related respiratory disease in employee leaving an electronics factory. Thorax 1979@ 34:19-22.

4 Burge PS, Harries MG, O'Brien IM, Pepys J: Respiratory diseases in workers exposed to solder flux fumes containing colophony (pine resin) Clin Allergy 1978; 8:1-14.

5 Slovak A, Hill N. Personal communication, 1979

6 Mitchell CA, Gandevia B. Respiratory symptom心 and skin reactivity in workers exposed to proteof lytic enzymes in the detergent industry. Am Re Respir Dis 1971; 104:1-12.

7 Burge PS, Perks WH, O'Brien IM et al. Occupa tional asthma in an electronics factory: a case control study to evaluate aetiological factors $\frac{D}{O}$ Thorax 1979; 34:300-7.

8 Newman Taylor AJ. MSc thesis. London: Univer $\vec{\bullet}$ sity of London, 1979.

9 Hunter JV, Dally MB, Hughes EG, Stewart M: Newman Taylor AJ. Skin test reactions to como mon inhalant allergens and to the complex salts of platinum in platinum refinery workers: के cohort study. In preparation, 1979.

10 Burge PS, O'Brien IM, Harries MG. Peak flov rates in the diagnosis of occupational asthma due to colophony. Thorax 1979; 34:308-16.

11 Burge PS, O'Brien IM, Harries MG. Peak flow rates in the diagnosis of occupational asthma due to isocyanates. Thorax $1979 ; 34: 317-23$.

12 Karol MH, Ioset HH, Alarie YC. Tolyl-specific IgE antibodies in workers with hypersensitivity to toluene di-isocyanate. Am Ind Hyg Assoc 1978; 39:454-8.

13 Zeiss CR, Kanellakes T, Bellone J, Levitz $\mathrm{D}_{-}^{-\frac{3}{8}}$ Pruzansky JJ, Patterson R. IgG and IgE antio body in two workers with diphenylmethane di isocyanate-induced respiratory disease. J Allergy? Clin Immunol 1979; 63:150-5.

14 Zeiss CR, Patterson R, Pruzansky JJ, Mille? MM, Rosenberg M, Levtiz D. Trimellitic anhyd ride induced airway syndromes. J Allergy Clin Immunol 1977; 60:96-103.

15 Maccia CA, Bernstein IL, Emmett EA, Brook\$ $\mathrm{SM}$. In vitro demonstration of specific IgE in phthalic anhydride sensitivity. Am Rev Respi Dis 1976; 113:701-4.

16 Cromwell O, Pepys J, Parish WE, Hughes EG Specific IgE antibodies to platinum salts in sensi tised workers. Clin Allergy 1979; 9:109-18.

17 Chan-Yeung M. Fate of occupational asthma $\frac{\text { Oे }}{\mathbb{D}}$ A follow-up study of patients with occupationa asthma due to Western Red Cedar (Thuja $\mathbb{Q}$ Plicata). Am Rev Respir Dis 1977; 116:1023-9.

18 Adams WG. Long term effects on the health of men engaged in the manufacture of tolylene di-isocyanate. $\mathrm{Br} J$ Ind Med 1975; 32:72-8. 
19 Fowler PBS. Printer's asthma. Lancet 1952; 2:755-7.

20 Roach SA, Schilling RSF. A clinical and environmental study of byssinosis in the Lancashire cotton industry. Br J Ind Med 1960; 17:1-9.

21 Juniper CP, How MJ, Goodwin BFJ, Kimshott AK. Bacillus subtilis enzymes: a 7 year clinical epidemiological and immunological study of an industrial allergen. J Soc Occup Med 1977; 27:3-12. 